Weed Technology

cambridge.org/wet

\section{Education/Extension}

Cite this article: Schroeder J, Barrett M, Shaw DR, Asmus AB, Coble H, Ervin D, Jussaume RA, Owen MDK, Burke I, Creech CF, Culpepper AS, Curran WS, Dodds DM, Gaines TA, Gunsolus JL, Hanson BD, Jha P, Klodd AE, Kniss AR, Leon RG, McDonald S, Morishita DW, Schutte BJ, Sprague CL, Stahlman PW, Steckel LE, VanGessel MJ (2018) Managing Wicked Herbicide-Resistance: Lessons from the Field. Weed Technol 32:475-488. doi: $10.1017 /$ wet.2018.49

Received: 9 February 2018

Revised: 14 May 2018

Accepted: 17 May 2018

\section{Associate Editor:}

William Johnson, Purdue University

\section{Key words:}

Herbicide resistance; herbicide resistance management; listening sessions; outreach

\section{Author for correspondence:}

J. Schroeder, U.S. Department of Agriculture Office of Pest Management Policy, Washington, DC 20250. (Email: jill.schroeder@oce.usda.gov)

(c) Weed Science Society of America, 2018. This is an Open Access article, distributed under the terms of the Creative Commons Attribution licence (http://creativecommons.org/licenses/ by/4.0/), which permits unrestricted reuse, distribution, and reproduction in any medium, provided the original work is properly cited.

\title{
Managing Wicked Herbicide-Resistance: Lessons from the Field
}

\author{
Jill Schroeder ${ }^{1}$, Michael Barrett ${ }^{2}$, David R. Shaw ${ }^{3}$, Amy B. Asmus $^{4}$, Harold Coble ${ }^{5}$, \\ David Ervin ${ }^{6}$, Raymond A. Jussaume Jr. ${ }^{7}$, Micheal D. K. Owen ${ }^{8}$, Ian Burke ${ }^{9}$, \\ Cody F. Creech ${ }^{10}$, A. Stanley Culpepper ${ }^{11}$, William S. Curran ${ }^{12}$, Darrin M. Dodds ${ }^{13}$, \\ Todd A. Gaines ${ }^{14}$, Jeffrey L. Gunsolus ${ }^{15}$, Bradley D. Hanson ${ }^{16}$, Prashant Jha ${ }^{17}$, \\ Annie E. Klodd ${ }^{18}$, Andrew R. Kniss ${ }^{19}$, Ramon G. Leon ${ }^{20}$, Sandra McDonald ${ }^{21}$, \\ Don W. Morishita ${ }^{22}$, Brian J. Schutte ${ }^{23}$, Christy L. Sprague ${ }^{24}$, Phillip W. Stahlman ${ }^{25}$, \\ Larry E. Steckel ${ }^{26}$ and Mark J. VanGessel ${ }^{27}$
}

\begin{abstract}
${ }^{1}$ Agronomist/Weed Scientist, U.S. Department of Agriculture Office of Pest Management Policy, Washington, DC, USA, ${ }^{2}$ Professor, University of Kentucky, Lexington, KY, USA, ${ }^{3}$ Giles Distinguished Professor of Weed Science, Office of Research and Economic Development, Mississippi State University, Mississippi State, MS, USA, ${ }^{4}$ Owner/Agronomist, CCA, RMS-Asmus Farm Supply, Inc., Rake, IA, USA, ${ }^{5}$ Professor Emeritus, North Carolina State University, Raleigh, NC, USA, ${ }^{6}$ Professor Emeritus of Environmental Management and Economics and Senior Fellow, Institute for Sustainable Solutions, Portland State University, Portland, OR, USA, ${ }^{7}$ Professor, Department of Sociology, Michigan State University, East Lansing, MI, USA, ${ }^{8}$ University Professor and Associate Chair Extension Weed Science, lowa State University, Ames, IA, USA, ${ }^{9}$ Associate Professor, Washington State University, Pullman, WA, USA, ${ }^{10}$ Assistant Professor, University of Nebraska-Lincoln, Panhandle Research and Extension Center, Scottsbluff, NE, USA, ${ }^{11}$ Professor, University of Georgia, Tifton, GA, USA, ${ }^{12}$ Professor, Penn State University, University Park, PA, USA, ${ }^{13}$ Associate Extension/Research Professor, Mississippi State University, Mississippi State, MS, USA, ${ }^{14}$ Assistant Professor (ORCID 0000-0003-1485-7665), Department of Bioagricultural Sciences and Pest Management, Colorado State University, Fort Collins, CO, USA, ${ }^{15}$ Professor, Department of Agronomy and Plant Genetics, University of Minnesota, Saint Paul, MN, USA, ${ }^{16}$ Cooperative Extension Specialist. (ORCID 0000-0003-4462-5339), University of California-Davis, Davis, CA, USA, ${ }^{17}$ Associate Professor, Montana State University, Southern Agricultural Research Center, Huntley, MT, USA, ${ }^{18}$ Extension Associate, Penn State University, University Park, PA, USA, ${ }^{19}$ Associate Professor (ORCID 0000-0003-2551-4959), University of Wyoming, Laramie, WY, USA, ${ }^{20}$ Assistant Professor (ORCID 0000-0002-1924-3331), North Carolina State University, Raleigh, NC, USA, ${ }^{21}$ Mountain West PEST, Ft. Collins, CO, USA, ${ }^{22}$ Professor of Weed Science and Extension Specialist, University of Idaho, Kimberly, ID, USA, ${ }^{23}$ Assistant Professor, New Mexico State University, Las Cruces, NM, USA, ${ }^{24}$ Professor, Michigan State University, East Lansing, MI, USA, ${ }^{25}$ Professor and Research Weed Scientist, Kansas State University, KSU Agricultural Research Center, Hays, KS, USA, ${ }^{26}$ Professor, University of Tennessee, Jackson, TN, USA and ${ }^{27}$ Professor, University of Delaware, University of Delaware Carvel Research and Education Center, Georgetown, DE, USA
\end{abstract}

\section{Abstract}

Herbicide resistance is 'wicked' in nature; therefore, results of the many educational efforts to encourage diversification of weed control practices in the United States have been mixed. It is clear that we do not sufficiently understand the totality of the grassroots obstacles, concerns, challenges, and specific solutions needed for varied crop production systems. Weed management issues and solutions vary with such variables as management styles, regions, cropping systems, and available or affordable technologies. Therefore, to help the weed science community better understand the needs and ideas of those directly dealing with herbicide resistance, seven half-day regional listening sessions were held across the United States between December 2016 and April 2017 with groups of diverse stakeholders on the issues and potential solutions for herbicide resistance management. The major goals of the sessions were to gain an understanding of stakeholders and their goals and concerns related to herbicide resistance management, to become familiar with regional differences, and to identify decision maker needs to address herbicide resistance. The messages shared by listening-session participants could be summarized by six themes: we need new herbicides; there is no need for more regulation; there is a need for more education, especially for others who were not present; diversity is hard; the agricultural economy makes it difficult to make changes; and we are aware of herbicide resistance but are managing it. The authors concluded that more work is needed to bring a community-wide, interdisciplinary approach to understanding the complexity of managing weeds within the context of the whole farm operation and for communicating the need to address herbicide resistance. 


\section{Introduction}

Weed science professionals have been tackling the problem of the evolution of resistance to herbicides for decades. Activities have included research and extension activities at regional and state levels, commodity group initiatives, national forums, symposia, reports, and summits plus training materials from the Weed Science Society of America (WSSA) and others (Table 1). Although these extensive efforts have been made to educate and inform stakeholders about the need to diversify weed management and adopt best management practices (BMPs) (Norsworthy et al. 2012), these efforts have produced mixed results at best.

Herbicide resistance is far from a new problem; reports of weeds evolving resistance to herbicides date from the early 1950 s (Heap 2017). However, the dramatic increase in herbicideresistant (HR) weeds this century and current discourse in agricultural circles regarding resistance to the herbicide glyphosate have brought the issue to a new level of attention. Awareness of herbicide resistance issues has certainly increased among farmers, consultants, retailers, weed scientists, industry representatives, and some government agencies. Despite the increased awareness, herbicide resistance continues to increase in scope and intensity (Heap 2017). Effective farmer engagement to manage HR weeds remains elusive, partly as a result of the socioeconomic realities of production agriculture. Our understanding of these realities, e.g., human-biology-technology interactions, is embryonic, and we need additional research to fill our knowledge gaps (Ervin and Jussaume 2014). Weed management decisions are only one component of a complex set of business and production decisions made each year by farmers. Since the 1950s, farmers' reliance on the discovery and development of new herbicide technologies to solve weed management problems has provided a false sense of security for weed management, as no new herbicide site of action has been commercially introduced in more than $30 \mathrm{yr}$ and none are likely to emerge from industry in the near future (Duke and Powles 2008, Stübler et al. 2016).

Although communication and awareness about HR has improved, farmers report that they receive conflicting messages from different sources. Further, we do not fully understand farmers' thinking about barriers to implementing BMPs or their successes in managing the HR problem. Government programs, such as certain conservation programs, as well as industry marketing programs and initiatives, may continue to limit farmers' abilities to make the needed management changes to address HR (CAST 2012; Norsworthy et al. 2012).

To make further progress, we felt that we needed to understand the grassroots concerns, challenges, ideas, and recommendations of farmers and others directly dealing with HR. We expected considerable differences among farmer types, regions, and cropping systems, and their associated weed management issues. As a first attempt to gather this information, the Herbicide Resistance Education Committee (HREC) of the Weed Science Society of America (WSSA), with the help of local weed scientists and professional facilitators, held seven meetings (regional listening sessions) around the United States (Schroeder et al. 2018). The objective of this paper is to summarize and interpret what we heard at the sessions.

\section{Methods}

Members of the HREC identified seven geographic regions in which to hold listening sessions based on the diversity of cropping systems and HR challenges. A planning team was assembled consisting of regional weed scientists (coordinators), professional facilitators, and WSSA HREC members. The regional coordinators were responsible for identifying a specific location in their region to hold the session and for inviting attendees to represent the key production systems, persons who influence weed management decisions, and the diverse demographics of the region.

The planning team developed the listening sessions after reviewing results from past programs and considering options for future efforts. The planning team developed three goals for the listening sessions: (1) gain an understanding of stakeholders and their goals and concerns related to herbicide resistance management (HRM); (2) gain an understanding of regional differences in $\mathrm{HR}$ issues and solutions, including successes and failures as well as challenges and needs; and (3) identify decision maker needs to address barriers to HRM adoption and how to assist them to overcome the barriers. During the course of the listening sessions,

Table 1. Previous national-level herbicide resistance activities.

- Two National Glyphosate Stewardship Forums were held in the 2000s, bringing farmers, commodity organizations, industry, and academia together to discuss the threat of glyphosate resistance.

- Symposia have been conducted at the annual conferences of the WSSA and regional society conferences for the last several decades.

- A 2010 report by the National Research Council (NRC) on the sustainability of genetically engineered (GE) crops for U.S. farms identified the threat of glyphosate resistance. The NRC report recommended the formation of a collaborative public-private effort to discover cost-effective resistance management practices and programs. The 2016 NRC report on the future of GE crops reaffirmed the need to address herbicide resistance.

- The WSSA developed a series of training modules for agronomic crops, turfgrass, non-cropland, and aquatic habitats that specifically addressed herbicide resistance management. A series of infographics have been created based on input from rural sociologists, economists, and crop consultants to more effectively educate end users on herbicide resistance management (http://wssa.net/wssa/weed/resistance/).

- The Council for Agricultural Science and Technology commissioned a special report in 2012 on the impact of herbicide resistance on soil conservation practices (CAST 2012, http://www.cast-science.org/publications/?

herbicideresistant_weeds_threaten_soil_conservation_gains_finding_a_balance_for_soil_and_farm_sustainability\&show=product\&productID=52723).

- The United States Department of Agriculture-Animal Plant Health Inspection Service (APHIS) commissioned a review of the literature associated with herbicide resistance (Vencill et al 2012) and recommendations and best management practices to reduce risk (Norsworthy et al 2012) (Open Access publications http://wssajournals.org/toc/wees/60/sp1).

- The WSSA worked with the National Academy of Science to conduct the first Herbicide Resistance Summit in 2012 to review best management practices, discuss the obstacles to their implementation, and present the recommendations from the APHIS-commissioned report to summit participants (NRC 2012, http://nas-sites.org/hr-weeds-summit/).

- A second Herbicide Resistance Summit, September 2014, discussed the "wicked" nature of the problem and how resistance will only be managed through the combined efforts of all parties involved (industry, university, government, retailers/dealers, consultants etc.). Therefore everyone needs to understand the role every person must play to address resistance in a constructive fashion. (Ward 2016, http://wssa.net/weed/resistance-summit-ii/).

- The U.S. Environmental Protection Agency proposed and sought comment in 2016 on consideration of herbicide resistance management measures in registration and registration review decisions and in 2017 published a final Pesticide Registrant Notice PRN 2017-2 that communicates their approach to addressing herbicide-resistant weeds by providing guidance on labeling, education, training, and stewardship (https://www.epa.gov/pesticide-registration/ prn-2017-2-guidance-herbicide-resistance-management-labeling-education). 
it became apparent that this third goal did not clearly identify who would provide this assistance and their needs. Thus, an added goal for this report became to bring more clarity to this objective.

Strategic Conservation Solutions, LLC, facilitated all of the sessions. During the listening sessions, participants were assigned to "tables" of approximately four to eight participants and were instructed to discuss several topics related to weed resistance. During those discussions, participants completed a short survey about their perceptions of weed resistance. The opening table discussion was designed to elicit the attendees' perspectives on HR. The second table discussion was designed to air the challenges the participants face from $\mathrm{HR}$ and what they need to address the problem. The session concluded with the participants offering their recommendations for what industry, farmers, universities, and governments need to do to address herbicide resistance. Participants then voted on which of the recommendations for action were most important to them for making progress in HRM. We initiated the voting process after the first listening session (Midsouth) was held, so no voting data exist for this session.

A companion paper (Schroeder et al. 2018) provides further details on the listening session process.

\section{Results and Discussion}

\section{Listening-Session Participants}

The listening sessions were conducted in seven locations (regions) across the United States to help the organizing committee appreciate some of the differences in experiences with weed resistance to herbicides. The regions were geographical agglomerations of states judged to have fairly homogeneous crop production conditions. Across the United States there are unique climatic conditions, weed species, and cropping systems. These and other differences could have an impact on the evolution of $\mathrm{HR}$ and thus perceptions of and experiences with HR as a problem. Considerable diversity exists within each region as a result of crop variations and agro-ecological conditions. These differences require caution against using uniform assessments of $\mathrm{HR}$ and control strategies within any region. Regional coordinators invited a mix of farmers and other stakeholders who are knowledgeable about $\mathrm{HR}$ and its impact on agriculture to the regional listening sessions to encourage a diversity of perspectives on HR. In the end, approximately one-third of the attendees self-identified as farmers, with the others coming from the ranks of retailers, landowners, pest control consultants, local and state land managers, and other relevant groups (Table 2; please see Schroeder et al. 2018 for the methods used by regional coordinators to identify participant demographics).

Although there was significant diversity based on region and work role, demographic and farm size diversity was minimal. For example, only a few minority farmers, women farmers, or supplier representatives were observed at the sessions. In addition, based on comments made throughout the meetings, it appeared that there were also fewer small-scale, alternative, or limitedresource farmers in attendance at the listening sessions. This lack of representation of the diversity of the U.S. agricultural population may have been the single biggest limitation to gaining a full understanding of farmer perspectives, challenges, and approaches to deal with HR. Many previous studies share this same limitation: a focus on farmers who manage farms above a certain acreage, and by default, income and size (George Frisvold, personal communication). The authors of this report recognize the extreme challenges facing researchers who attempt to understand the diversity of the agrarian experience in the United States. Although this does not diminish the value of the listening sessions that we conducted, it is important to recognize that the sessions may not have captured the full diversity of farmer issues and needs across the United States with respect to HRM.

Table 2. Participant demographics at the regional listening sessions, based on self-identification on table survey forms. ${ }^{a}$

\begin{tabular}{|c|c|c|c|c|c|c|c|}
\hline \multirow[b]{2}{*}{ Primary occupation } & \multicolumn{7}{|c|}{ Region } \\
\hline & Midsouth & Mid-west & Northeast & Northwest & Plains & Southeast & Southwest \\
\hline Grower & 40 & 29 & 16 & 17 & 43 & 19 & 14 \\
\hline Landowner & 27 & 22 & 12 & 11 & 33 & 8 & 6 \\
\hline Commodity leader & 5 & 15 & 4 & 4 & 6 & 2 & 2 \\
\hline Ag supplier & 35 & 12 & 24 & 8 & 9 & 5 & 9 \\
\hline Pest control consultant & 21 & 3 & 22 & 13 & 17 & 4 & 17 \\
\hline Local/state/federal land manager & 9 & 3 & 3 & 3 & 6 & 1 & 4 \\
\hline Dryland & - & 26 & 37 & 31 & 43 & 18 & 3 \\
\hline Irrigated & - & 26 & 11 & 19 & 37 & 17 & 22 \\
\hline Other & - & - & 1 & - & 1 & - & 2 \\
\hline
\end{tabular}

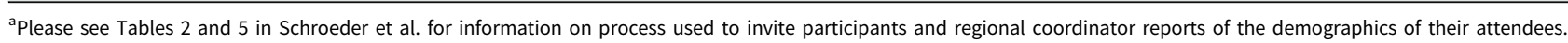




\section{What Was Said at the Listening Sessions}

All participants were invited to share, on a form that was collected during the listening sessions, their role in the agricultural industries as well as their individual perspectives on whether they (a) thought HR is a problem, (b) were concerned about the spreading of HR from county to county, (c) were concerned about the spreading of HR from field to field, and (d) were concerned about the spreading of HR from region to region.

Our analysis of the data collected begins with comparing farmer and non-farmer perspectives on the above four concerns. Of all participants who returned forms to us, $15.1 \%(N=72)$ identified themselves as farmers, $22.6 \%(N=108)$ farmed as well as worked at other jobs, and $62.3 \%(N=297)$ identified themselves as non-farmers. Our analysis discerned no significant differences between farmer and non-farmer responses to any of the four questions about HR. Ninety-five percent of all participants agreed or strongly agreed that HR is a problem. Participants in the Great Plains, Southeast, Midsouth, and Northwest regions were more likely to respond that HR is a critical problem than those in the other regions (Table 3 ). This variation in perceived severity of HR may reflect the uniqueness of agricultural production systems in each region, and in particular in the Northeast and the Southwest regions.

Overall, recognition of $\mathrm{HR}$ as a problem was nearly universal in all regions. This suggests that regional differences in the views expressed about HR were less important than many of the other

Table 3. Bivariate analysis ${ }^{a}$ of listening-session participant perspectives on whether HR is a problem by region.

\begin{tabular}{|c|c|c|c|c|}
\hline \multicolumn{5}{|c|}{$\begin{array}{l}\text { Number and percentage of participants in a region who stated that } \\
\text { herbicide resistance is: }\end{array}$} \\
\hline Region & $\begin{array}{l}\text { NOT a } \\
\text { problem }\end{array}$ & A Problem & $\begin{array}{l}\text { A CRITICAL } \\
\text { problem }\end{array}$ & Total \\
\hline \multirow[t]{2}{*}{ Great Plains $^{\text {b }}$} & 2 & 27 & 58 & 87 \\
\hline & 2.30 & 31.03 & 66.67 & 100.00 \\
\hline \multirow[t]{2}{*}{ Southeast } & 0 & 14 & 22 & 36 \\
\hline & 0.00 & 38.89 & 61.11 & 100.00 \\
\hline \multirow[t]{2}{*}{ Northeast } & 1 & 36 & 26 & 63 \\
\hline & 10.59 & 57.14 & 41.27 & 100.00 \\
\hline \multirow[t]{2}{*}{ Southwest } & 6 & 22 & 18 & 46 \\
\hline & 13.04 & 47.83 & 39.13 & 100.00 \\
\hline \multirow[t]{2}{*}{ Midsouth } & 1 & 39 & 108 & 148 \\
\hline & 0.68 & 26.35 & 72.97 & 100 \\
\hline \multirow[t]{2}{*}{ Northwest } & 0 & 17 & 34 & 51 \\
\hline & 0.00 & 33.33 & 66.67 & 100 \\
\hline \multirow[t]{2}{*}{ Midwest } & 3 & 20 & 18 & 41 \\
\hline & 7.32 & 48.78 & 43.90 & 100.00 \\
\hline \multirow[t]{2}{*}{ Total } & 13 & 175 & 284 & 472 \\
\hline & 2.75 & 37.08 & 60.17 & 100.00 \\
\hline
\end{tabular}

${ }^{\mathrm{a}}$ Pearson $\chi^{2}(12)=55.2718 \mathrm{Pr}=0.000$

${ }^{\mathrm{b}}$ Cell contents: In each cell, the top number is the actual number of respondents, and the bottom number is the corresponding percentage of all respondents in that region. views that were shared across regions. Ninety-five percent of all participants also agreed that the spreading of HR weeds from field to field is a problem, whereas approximately $80 \%$ agreed or strongly agreed that spreading HR weeds from county to county and region to region are problems. These results parallel those obtained from a national sample of U.S. farmers from at least 28 states, where nearly $90 \%$ of all respondents reported they were concerned about HR on their farms (Jussaume and Dentzman 2016). Further, just under $72 \%$ of all respondents to that survey strongly agreed or agreed that they were concerned about HR weeds spreading to their farms from nearby farming operations (Ervin et al. 2017).

Another exercise that was conducted during the listening sessions (except at the initial Midsouth session) was to ask participants to list what they perceive as the top challenges and barriers as well as the top wants and needs for managing HR. In a subsequent exercise, participants in the six regions were asked to "vote" on what they thought were the top three challenges and barriers, and the top three wants and needs (Tables 4 and 5). In interpreting these data, it is important to remember that most attendees expressed the viewpoint that HR is a problem, including $61 \%$ who reported that HR is a critical problem. Comments we heard during the listening sessions support these findings and indicate to us that the participants at the sessions thought that HR weeds pose a shared problem for all entities in a community who manage weeds. Attendees saw the problem of HR as bigger than what they can address on their own and that HR is a threat related to the actions of others, including non-agricultural groups.

Although most participants recognized that HR is a problem, the same individual attendees, including most of the farmers, seemed to feel that they are managing HR with some degree of success, at least for the time being. As one attendee stated during one of the discussion periods, "It's (HR) a problem, but it's a manageable problem." However, many attendees also expressed concern that HR could become an increasing challenge should weeds evolve resistance to more herbicides and/or spread over greater areas. Concerns also were expressed regarding a continued loss of viable herbicide options. One attendee said that "If Liberty $^{\mathrm{TM}}$ [glufosinate, an herbicide that is currently effective] fails...," whereas in another region someone said, "If we lose Valor $^{\mathrm{TM}}$ [flumioxazin] and Reflex ${ }^{\mathrm{TM}}$ [fomesafen], we could be in trouble." These statements also underscore the over-reliance on herbicides alone for weed management.

Given this context, it should not be surprising that when the challenges and barriers as well as the wants and needs were reported, the leading viewpoint expressed was a concern over the lack of new chemistries and new modes of action (MOAs, the terminology used by stakeholders) (as barriers) and the desire for new MOAs or new technology and herbicide products (as a need). Many attendees also expressed a belief that one reason new MOAs are not forthcoming is regulatory barriers. Thus, they cited "regulatory/red tape" and "cost/time of registration" as key barriers to new MOAs, while citing "less regulation" as a top need. A strong expectation, and hope, expressed during the listening sessions was that a new, powerful MOA is just over the horizon. Recommendations to government agencies that included "timely regulatory approvals" and "speed to market" reflected this hope. It should be noted, however, that participants are not against all regulation, as some participants also recommended regulatory efforts like "tighter noxious-weed rules" and "standardized labelrotation (required rotation of herbicide products, presumably MOA rotation)-up-front information" to be in effect. 
Table 4. The top three wants and needs identified by region. ${ }^{a}$

\begin{tabular}{|c|c|c|c|c|c|}
\hline $\begin{array}{l}\text { Northeast/ } \\
\text { Pennsylvania }\end{array}$ & $\begin{array}{l}\text { Northwest/ } \\
\text { Washington }\end{array}$ & $\begin{array}{l}\text { Southwest/ } \\
\text { California }\end{array}$ & $\begin{array}{l}\text { Plains/ } \\
\text { Colorado }\end{array}$ & $\begin{array}{l}\text { Midwest/ } \\
\text { Texas }\end{array}$ & $\begin{array}{l}\text { Southeast/ } \\
\text { Georgia }\end{array}$ \\
\hline $\begin{array}{l}\text { New modes of } \\
\text { action }\end{array}$ & New modes of action ( $23.2 \%)$ & $\begin{array}{l}\text { More education on } \\
\text { the issue }\end{array}$ & $\begin{array}{l}\text { More } \$ \text { for university } \\
\text { research }(17.7 \%)\end{array}$ & $\begin{array}{l}\text { New technology/products } \\
(21.4 \%)\end{array}$ & $\begin{array}{l}\text { New modes of action } \\
(23.3 \%)\end{array}$ \\
\hline $\begin{array}{l}\text { More education/ } \\
\text { farmer-farmers }\end{array}$ & $\begin{array}{l}\text { IPM diversity/minimize selection } \\
(15.2 \%)\end{array}$ & $\begin{array}{l}\text { Comprehensive } \\
\text { management } \\
\text { solutions (public/ } \\
\text { private) }\end{array}$ & $\begin{array}{l}\text { Grower education } \\
\qquad(10.1 \%)\end{array}$ & Grower education (21.4\%) & $\begin{array}{l}\text { More collaboration } \\
\text { between growers, } \\
\text { universities, farmers } \\
(20 \%)\end{array}$ \\
\hline $\begin{array}{l}\text { N.B. No votes } \\
\text { reported on } \\
\text { wants/needs }\end{array}$ & $\begin{array}{l}\text { Extended patent protection AND } \\
\text { EPA consideration of H.R. in } \\
\text { process ( } 10.6 \% \text { each) }\end{array}$ & $\begin{array}{l}\text { Cost-benefit analysis } \\
\text { of solutions to } \\
\text { problem }\end{array}$ & $\begin{array}{l}\text { Less regulation to } \\
\text { bring new } \mathrm{A} \text {. I. to } \\
\text { market }(8.8 \%)\end{array}$ & $\begin{array}{l}\text { Collaborative communication } \\
\text { (industry, community, farm } \\
\text { organizations) (12.6\%) }\end{array}$ & $\begin{array}{l}\text { Farm bill policy that } \\
\text { supports diversity } \\
(13.3 \%)\end{array}$ \\
\hline
\end{tabular}

${ }^{a}$ The process of tallying votes to identify the top needs and wants did not start until after the Midsouth session.

${ }^{b}$ Abbreviations: A.I., active ingredient; HR, herbicide resistance; IPM, integrated pest management.

Another important theme that emerged in many of the listening sessions and expressed in the voting on challenges/barriers/wants/needs was the barrier/challenge of economics. Specifically, farmers said in several sessions that it is difficult to spend more money on weed management, as well as other management challenges, when commodity prices are low. In other words, the amount of funds available for farmers to address management challenges is linked to commodity sales revenue. Comments in this vein made by farmers included statements such as, "Everything is budgeted based on my operation, but when you deal with Palmer (amaranth) you have to throw the budget out the door," "Nobody wants to spend extra dollars," and "Farmers are struggling to control these weeds at an economic level."

The need for more education, particularly for "others" who were not part of the listening sessions, was also a theme that cut across many sessions. Recommendations for "training and education" of industry, "educate your government officials," and "more education on the issue" directed at non-agricultural society were expressed in several sessions. A corollary of this was the expressed need for more communication and collaborative action between governments (federal, state, and local), between different government agencies, between farmers and non-farm groups, and between universities, private-sector firms, and the government. A few participants also encouraged others in attendance to recognize that "It's our problem, not just our neighbors' problem."

In contrast, expressed on several occasions was the theme that weed resistance to herbicides is something that happened to participants and that a primary responsibility for causing and managing resistance was in the hands of others. For example, many participants felt that the problem had been "imported" from other regions of the country via biological processes, machinery movement, and commodity shipments such as livestock feed. This sentiment aligns with the high percentage of participants who are concerned about HR spreading between counties, states, and regions. If this is an accurate reflection of participants' views, then the reluctance to take shared ownership of the problem, accepting that all farmers contribute to the problem by the way in which they use herbicides, equipment, and source inputs such as seed and feed, may pose a significant challenge to formulating effective HRM programs. In other words, because HR is a landscape-level problem that necessitates a community-level approach to management, it is important for all parties, both inside agriculture or outside, to take ownership of the problem and to recognize the community-wide nature of the problem and possible solutions for the issue of HR.

A final overarching theme was that diversity is difficult. Some participants noted the lack of profitable alternative crops for rotations or challenges in using cover crops making the inclusion of greater HRM diversity difficult. Weed scientists often consider these two tactics to be among the very best of BMPs (Norsworthy et al. 2012), but farmers often do not consider them viable when viewed through their economic lens. Limitations described ranged from a lack of adapted crops for a particular climate/region, to low economic return of alternative crops, to expensive equipment requirements for different crops, to difficulty in managing a variety of crops. Agricultural professionals often encourage the use of diverse tactics, e.g., varying herbicide MOAs and planning crop rotations, as a core element of effective HRM. However, many participants felt that new herbicide chemistries are their preferred response to the HR problem. Many farm operations had adapted their operation to take advantage of the simplicity of the Roundup Ready system (e.g., glyphosate-resistant crops with

Table 5. The top three barriers and challenges identified by region. ${ }^{a}$

\begin{tabular}{|c|c|c|c|c|c|}
\hline $\begin{array}{l}\text { Northeast/ } \\
\text { Pennsylvania }\end{array}$ & $\begin{array}{l}\text { Northwest/ } \\
\text { Washington }\end{array}$ & $\begin{array}{l}\text { Southwest/ } \\
\text { California }\end{array}$ & $\begin{array}{l}\text { Plains/ } \\
\text { Colorado }\end{array}$ & $\begin{array}{l}\text { Midwest/ } \\
\text { Texas }\end{array}$ & $\begin{array}{l}\text { Southeast/ } \\
\text { Georgia }\end{array}$ \\
\hline $\begin{array}{l}\text { Low profit margins } \\
(24.7 \%)\end{array}$ & $\begin{array}{l}\text { Loss of chemistry } \\
\quad(14.5 \%)\end{array}$ & $\begin{array}{l}\text { Education on the issue, } \\
\text { grower/PCA }\end{array}$ & $\begin{array}{l}\text { Regulatory/red } \\
\text { tape }(19.5 \%)\end{array}$ & $\begin{array}{l}\text { Scouting/timing/education } \\
(27.3 \%)\end{array}$ & $\begin{array}{l}\text { More education } \\
\quad(27.1 \%)\end{array}$ \\
\hline $\begin{array}{l}\text { Need new modes of } \\
\text { action }(16.5 \%)\end{array}$ & $\begin{array}{l}\text { Lack of alternative } \\
\text { crops }(13.8 \%)\end{array}$ & $\begin{array}{l}\text { Policy maker knowledge, } \\
\text { agronomists' voice heard }\end{array}$ & Economics (15.9\%) & $\begin{array}{l}\text { Economics (grain prices) } \\
(21.2 \%)\end{array}$ & $\begin{array}{l}\text { Need new modes } \\
\text { of action }(23.5 \%)\end{array}$ \\
\hline
\end{tabular}

${ }^{a}$ The process of tallying votes to identify the top needs and wants did not start until after the Midsouth session.

bAbbreviation: PCA, Pest Control Adviser. 
primary or sole reliance on glyphosate for weed control), and the farmers' view that returning to a more diverse (and more complicated) weed management program is impossible.

Overall, it was apparent to us as observers that farmers and other key stakeholders recognize the problem of $\mathrm{HR}$ and are concerned that the challenge of managing HR weeds may increase over time. Overall, the leading hope was that inexpensive and effective new herbicides will be forthcoming that would enable farmers to manage weeds easily. Although some invited panel speakers mentioned their use of multiple strategies to manage weeds, there was little discussion of integrated-management approaches or, more importantly, of the need for communitybased efforts to combat HR.

\section{Interpretation of What Was Said}

In this section, we attempt to interpret key themes expressed by listening-session participants, needs/wants and barriers/challenges, themes that emerged from stakeholder discussions in relation to the recent scientific findings on HRM.

\section{Key Theme: We Need New Herbicides, Especially with new} Modes of Action

The organizing committee was surprised after the first listening session in the Midsouth at the strength of the sentiment that the number 1 want/need to solve HR was new herbicides, particularly ones with new MOAs. In the subsequent six sessions when we polled participants, "new herbicides" was the top vote getter in four sessions and was alluded to in a fifth (the wants/needs expressed at the Plains session were for less regulation to allow new active ingredients to come to the market) (Table 1). This is consistent with what others (Dentzman et al. 2016, Dentzman and Jussaume 2017, Foresman and Glasgow 2008, Llewellyn et al. 2002) discovered through both qualitative and quantitative research on farmers' perceptions about HR. Dentzman et al. (2016) termed this hope and belief that new herbicides would become available to solve the HR problem as "techno-optimism." However, is this optimism justified? The listening-session participants seemed to believe that regulation and, in particular, the Environmental Protection Agency (EPA) was a main reason for the lack of discovery and development of new herbicide MOAs. In contrast, Duke (2012) suggested that the most important reason there are no new herbicides with a unique MOA lies in factors such as a reduced herbicide market after engineering glyphosate resistance into some major crops and the attitude that the discovery of "easy" herbicide target sites in the plant is past, with new targets being harder to discover and develop. Although not specifically mentioned, there was a sense that participants were looking for an herbicide that would work like glyphosate, in that it would be easy to use, be effective against a broad spectrum of weeds, and would provide excellent weed control without requiring an integrated approach to weed management. Although this desire is understandable, many in the agricultural industry may not realize what an extraordinary and rare discovery glyphosate was (Duke and Powles 2008). The belief that new herbicides will soon be available to solve the HR problem will probably retard the adoption of HRM. Llewellyn et al. (2007) found in a survey of Australian farmers that those who believed that new herbicides would soon be available were less likely to adopt HRM practices than farmers who were uncertain about the availability of a new herbicide.
How much does regulation, including EPA oversight, actually contribute to the cost of developing a new herbicide? The EPA processing cost for a new active ingredient, from initial experimental use through final approval for food use (the most expensive case), is $\$ 627,568$ (Anonymous 2017c). Of course, these fees are only a very small part of the cost for developing a new herbicide. McDougall (2016) estimated that \$33 million of the total $\$ 286$ million cost of bringing a new pesticide to market during 2010 through 2014 was required to prepare and submit the required data to European and U.S. regulatory agencies along with the subsequent negotiations with the agencies. This is $\$ 20$ million more for regulatory approval than was required in 1995 when the overall cost for developing a pesticide was estimated to be $\$ 152$ million. The rest of the increased cost ( $\$ 114$ million) for bringing in a new herbicide over this period included $\$ 33$ million more for required toxicology and environmental chemistry testing during the development phase. The largest part of the increase (\$64 million) was from the higher costs of new pesticide discovery and field testing. Of course, inflation alone would have increased the cost of business over the 20 -yr period McDougall examined. Using the GDP price deflator (Anonymous 2017a), it can be estimated that the $\$ 152$ million cost in 1995 would have grown to $\$ 236$ million by 2014 . Although many of the listening-session participants thought that increased regulatory cost was inhibiting herbicide discovery and development, these numbers do not provide unambiguous support for that position. Part of the overall conclusion of Stübler et al. (2016) is that the increased cost of discovery and development is certainly one factor preventing new MOAs from coming to the market; however, now there is also a longer time between synthesis and sales of new crop protection chemistry. McDougal (2016) estimated that the time has increased from an average of $8.3 \mathrm{yr}$ in 1995 to $11.3 \mathrm{yr}$ in 2010 through 2014. This also represents an increased "cost." It is at least a loss of $3 \mathrm{yr}$ of patent protection before sales of any new chemistry. McDougal states that this increased time "could reflect greater complexity in the data requirements of regulatory bodies," or "it could also indicate the time taken to satisfy the regulators." $\mathrm{He}$ also listed diversion of research expenditures to biocontrol and seeds and traits as inhibitory toward new MOA discovery.

Stakeholders also expressed the sentiment that if only industry worked harder and invested more it would discover new herbicides. In a recent presentation, Herman Stübler, Head of Weed Control Research at Bayer CropScience, emphasized that the HR crop technology discouraged new herbicide discovery, with some companies even abandoning the effort (Stübler et al. 2016). Although companies are starting to put more effort into herbicide discovery, it was his opinion that for the next 10 to $15 \mathrm{yr}$ we will need to preserve the existing herbicide options. This is consistent with McDougall's (2016) estimate that it would be more than 11 yr before any new crop protection MOA will be commercially available. Educators need to focus more on the increased difficulty of herbicide discovery and the time between discovery and sales of any fundamentally new herbicides. There have even been suggestions that HR could bring the "age of herbicides" to an end (Davis and Frisvold 2017).

A related question is whether the chemical industry fosters the perception and attitude that new herbicides could be available soon. Industry management knows there is no "next best chemistry" in the development pipeline, but so long as some farmers believe that it is easy to create another herbicide and that a new one will be available soon, they may not even consider other, more complex and integrated options (Dentzman et al. 2016, Dentzman 
and Jussaume 2017). Moreover, the release of new tools like dicamba- and 2,4-D-resistant soybean and cotton varieties gives farmers hope for a new "silver bullet." In addition to the new "silver bullet" phenomenon, farmers often become confused and equate the use of an "old herbicide" on a new resistance trait to a new MOA. It is important to help the farmer understand that many weeds are already predisposed to this old herbicide, and the durability of value to this approach has been very limited. It would be well if farmers recognize that none of the new selective chemistries will replace glyphosate. However, industry marketing campaigns may make farmers believe the new products will provide better and longer weed control. Statements like those of Robert Fraley, Executive Vice President and Chief Technology Officer, Monsanto Company ["Once you get to the point where you have three (chemistry) modes of action on that field, your odds of weed-resistance development pretty much drop to zero"], implying that HR would be eliminated by 2050 , could encourage many farmers to wait for new technologies even while resistance to the existing MOAs increases (Pates 2016). The question is, what is the effect on farmers when industry simultaneously says that (a) new MOAs are not around the corner and we have to steward what we have, and (b) the solution is right around the corner and there is nothing to worry about? The answer is that farmers probably choose to believe the optimistic message (Dentzman et al. 2016).

\section{Key Theme: There Is No Need for More Regulation}

It was not surprising to us that participants at most sessions expressed a general disdain for more regulation to help deal with HR. Although the participants directed most of their negative opinions on regulation toward national-level regulators, participants at the Southwest session from California did mention that they were more concerned with state-level regulation that would add further restrictions to federal herbicide labels.

The one session where participants were more open to regulation as part of the solution was the Northeast. This region was unique among the seven sessions by having a long history of dealing with HR. The Northeast was one of the first regions to deal with triazine resistance in no-till systems, glyphosateresistant horseweed, and issues with acetolactate synthase-inhibitor resistance in vegetable crops (Heap 2017). However, the participants were at least as concerned with the introduction of Palmer amaranth into their area as they were with HR. A desire to keep Palmer amaranth from becoming established and widespread possibly led to some of their favorable attitude toward regulation. Palmer amaranth is already on the Delaware noxiousweed list (Anonymous 2017b), and a participant related how the law had been used to force a farmer to clean up a field infestation of Palmer amaranth. Pennsylvania is also considering adding Palmer amaranth to its noxious-weed list.

Participants in the Northeast session seemed more to recognize that regulation might be necessary-if not really wanted-to help deal with "bad actors." No one wanted to be affected personally by regulation, but many thought it might be needed to deal with their neighbors. One participant described grassroots efforts that brought a group together to eradicate a localized new infestation of Palmer amaranth.

Was this different attitude in the Northeast session just due to concerns with Palmer amaranth as an outside threat, or does the nature of the farms and farming (generally smaller and in many cases more diverse) in comparison to the other regions contribute to this different mindset? Alternatively, is their experience with resistant weeds making them more proactive and aggressive in this case to avoid potentially serious problems? These are important questions that must be addressed in future research on farmer approaches to managing HR.

The attitude toward regulation was different in the other regions. The commonly expressed concern in some of the other listening sessions was that some individuals were doing the right things themselves but others were not, and this was worsening HR. This led to expressions of helplessness, as many individuals stated that, regardless of what an individual did, HR problems would continue because of the actions of others. However, whereas collective action to address HR is the best approach, there are examples showing that following HR BMPs as an individual, even when neighbors are not, is still a better approach economically than not using BMPs (Livingston et al. 2015; Livingston et al. 2016). Whether some type of collective approach would improve on that economic return depends on the extent of HR weed mobility, the feasibility of control, crop rotation, and the cost of organizing the collective effort. Research from other industries found that the perceived threat of regulation is associated with more voluntary use of environmental management practices (Ervin et al. 2013). In other words, the threat of regulation can motivate changes in behavior so as to avoid the implementation of that regulation.

It would have been interesting to get the participants reaction to the recent pesticide and HRM guidance from the EPA to registrants (Anonymous $2017 \mathrm{~d}, \mathrm{e}$ ), the elements and suggestions of which are already appearing on labels of herbicides such as Enlist Duo ${ }^{\mathrm{TM}}$, Engenia $^{\mathrm{TM}}$, and XtendiMax with VaporGrip ${ }^{\mathrm{TM}}$ Technology.

\section{Key Theme: There Is a Need for More Education}

We heard that there was a need for more education about HR both for "others" (especially those who did not attend these meetings) and for farmers. Many participants also expressed a need for more communication and collaboration between all of the stakeholders involved in agricultural production.

The need for more education for "others" reflects a sense from the participants that the behavior of "others" is the problem and that "others" are causing HR problems for the participants. Movement of weed seed across landscapes and regions is one mechanism for introduction of species and resistant biotypes into a new area. However, participants did not appear to acknowledge the contribution of selecting for resistance in a local population through repeated herbicide use in an individual field. Although a few participants did express the sense that they themselves bear some responsibility for the problem of $\mathrm{HR}$, a more common sentiment was that resistant weeds either moved locally or from farther away to participants' fields. This opinion is contrary to results of empirical studies such as those of Neve et al. (2011) showing that HR can be widely selected for across a landscape. These authors predicted that glyphosate resistance would be selected in $39 \%$ of Palmer amaranth populations with $5 \mathrm{yr}$ of annual applications and in $60 \%$ of the populations after $10 \mathrm{yr}$ of annual use. This is consistent with field experience. Another study found as much overall genotypic diversity occurring in amaranth populations within a state as between states (Chandi et al. 2013). Perhaps more education needs to be directed toward farmers' understanding that there is a high probability of selecting for HR on their own fields, as well as education about preventing importation of HR. 
It was interesting that there was a call for more education for farmers. Our perception is that a plethora of educational opportunities to learn about HR is delivered in print, electronically, or through face-to-face meetings. One of our motivations to conduct the listening sessions was to address the feeling that, despite a lot of education on the subject of HR from many public and private organizations, behavior has not changed enough to stem the evolution of HR. Although lack of knowledge about HR may be a factor, just as important in understanding the failures to adopt HR BMPs may be such influences as agronomic conditions, economic realities, or cultural background and upbringing, plus the behaviors of other actors in the agro-food system. Certainly, the ease and flexibility of the glyphosate-based weed management system probably contributed to the continued increase in U.S. farm size (Anonymous 2018). The added time and management expertise required to deal with HR weeds complicates the adoption of more complex and diverse weed management approaches for these larger scale farms, where balancing weed management with other on-farm imperatives are a real challenge.

System approaches to weed management are not "products" that can be sold. As such, this type of information will be undersupplied by the private sector. Sustainable weed management systems may incorporate non-chemical sellable inputs such as cover crops and "seed destructors" (Walsh et al. 2013). However, knowledge of the overall management system and impacts on longterm weed management involves the public good, and it is difficult for the private sector to capture gains from such knowledge. Therefore, it may not be all that surprising that farmers want "education," which they may see as different from "products." Although it may be difficult for the chemical industry to profit from farmers' adoption of weed management systems, knowledge of how to incorporate these practices into a farmer's production system at the local level does have value. Professional advisers with this capacity will be valued, as will extension specialists sharing this information. Adoption of more diversified weed management systems also has value in that it could extend the useful life of herbicides that are experiencing serious HR challenges.

Participants said that there is a need for more communication and collaborative action among different government levels (e.g., federal, state, and local), among different governmental agencies, among farmers and non-farm groups, and among universities, private-sector firms, and the government. Perhaps the problematic issue is not the amount of educational material available about HRM but rather confusion from conflicting messages or a perception that current educational efforts are not effective. We need to make more effort to assess the effectiveness of different educational programs and approaches in conjunction with other influencing factors that may diminish their efficacy or play synergistic roles. We also do not understand (a) why industry is providing conflicting messages and (b) what is the effect of that conflicting messaging.

\section{Key Theme: Diversity Is Difficult}

Some listening-session panel speakers mentioned their use of multiple strategies to manage weeds, but overall, there was little discussion of integrated management approaches. Diversity in weed management strategies is a key element in HRM (Norsworthy et al. 2012) that in fact is considered vital for sustainable future weed management (Owen et al. 2015). Listening-session participants recognized this, but there were also dramatic differences between regions as to whether farmers could incorporate more diversity into weed management and cropping practices. As stated above, some participants understood the advantages of crop rotation but also believed that they did not have profitable rotational crop options. Similarly, they recognized that cover crops are an effective tool for weed management but that the economics and practicality of cover crops are unfavorable in many regions and cropping systems.

The ultimate goal of HRM is greater diversity in the entire cropping system (Davis et al. 2012) and weed management systems (Owen 2016), but a first step would be effective diversity in herbicide programs. It is recognized that herbicides will be part of the weed management system for the foreseeable future (Owen 2016). Some studies (Beckie and Reboud 2009; Evans et al. 2016) have shown, with some caveats, that using mixtures of herbicides with different MOAs that are all effective against the target weeds can delay the evolution of HR much more effectively than simply rotating MOAs. The challenge is to identify these mixtures and communicate that to farmers. Rotating or mixing MOAs may prove quite challenging, as industry surveys (Arlene Cotie, personal communication) found that only a small proportion of farmers, fewer than $30 \%$, understand the MOAs of available herbicides, although this number has increased in the last $2 \mathrm{yr}$. We do not understand what farmers mean when they state, on a survey, that they do not understand MOAs, nor do we know how advisers (industry salespersons, retailers, consultants, or others) describe herbicide MOA as they discuss weed management decisions with farmers. New instructions from the EPA to registrants to include MOA information on labels (Anonymous 2017d) may facilitate continued education on how to use this information.

Introducing diversity beyond herbicide diversity, seen as necessary to fully delay evolution of HR (Evans et al. 2016), will require more reliance on non-chemical weed control approaches (e.g., tillage, crop rotation, cover crops, weed seed destruction; Walsh et al. 2013). Non-chemical tactics require more labor and equipment, and some practices can have dramatic negative impacts on conservation tillage programs and compliance with USDA-NRCS conservation tillage programs (CAST 2012). This is not to say that these non-chemical weed management approaches will not have a place in future weed management systems. How attractive they are to producers will depend on their further development to fit into crop production systems and the continued evolution of HR. The programs will also certainly vary across regions in the United States.

Listening-session participants felt that implementing more integrated weed control programs was impossible without dramatically changing entire farming operations and the economics of these systems. This was a major reason why they wanted a new herbicide chemistry, because that is a solution that more easily fits within the current structure of agriculture and associated agricultural practices. However, in the face of extreme weed pressure farmers have been known to change their practices. A prime example is Georgia cotton farmers who were willing to spend more on herbicides, introduce tillage into their operations, and use hand-weeding crews so as to control HR Palmer amaranth (Sosnoskie and Culpepper 2014). Another approach would be to introduce new weed management tactics that diversify the approach to control while being compatible with the current farming systems. This is the objective in approaches to harvesttime weed seed destruction (Walsh et al. 2013).

One contrast between the regions was their current use of crop diversity. In the Great Plains listening session, there were comments about how hard it was to have crop diversity. In the 
Midwest region, participants stated that it is a struggle to find profitable crops other than corn and soybeans. On the other hand, participants in both the Southwest and Northeast sessions recognized that their crop diversity was very effective in combatting or even preventing HR. This regional diversity in crops is a reminder that HRM must be adapted locally; there are no onesize-fits-all solutions. Locally adapted HRM plans must take into account factors such as the crops suitable for an area, water availability for dryland or irrigated production, available labor and management, community networks, and the relative profitability of different crops. In addition to these, the plan must include affordable crop input costs, the potential for profitable crop yields given the environment and soil resources, and marketing opportunities for any alternative crops.

We need more research and education on viable crop rotation alternatives and diversifying weed management programs. The land-grant universities need to emphasize and search for economical applications of cover crops, use of rotations, and more diverse cropping systems. They also need to conduct research and outreach on how to incorporate these practices into current production systems. An example of one such effort is the "Forever Green Initiative" at the University of Minnesota (Anonymous 2017f). Some basic questions deserve more research. How diverse does a weed management program have to be to effectively delay HR evolution? How can we resolve conflicts between including tillage for HRM and minimizing tillage for soil conservation?

Beyond diversity gained from different crop species, we can also consider diversity from varieties within a crop species. We heard a few comments like "Do we really need to use glyphosateresistant crops $100 \%$ of the time?" Many seed companies work to incorporate a trait(s) across as many crop systems and into as many crop cultivars as possible, as this reduces the costs of carrying a more diverse crop seed inventory. However, it also channels farmers into certain incentivized programs built around specific crop trait(s), and that decision, in turn, may influence their herbicide choices. This is especially true for corn, soybeans, and cotton. At the present time, glyphosate, glufosinate, dicamba, and 2,4-D resistance have been incorporated into these crops. The selection pressure for HR will be very high if the same suite of herbicides is used on land that is rotated between these crop cultivars. Having once purchased seed with a particular herbicide tolerance trait, growers have a natural tendency to want to use that herbicide to maximize the returns to their investment. Practicing crop rotation in this case may not result in practicing herbicide chemistry rotation.

\section{Key Theme: The Current Agricultural Economy Makes It} Difficult to Do things Differently

Listening-session participants identified economics, especially related to the current commodity prices, as one of the top barriers to HRM in three of the listening sessions (Table 3). This idea also pervaded discussions in most of the other listening sessions. The one exception to this may have been the specialty-crop farmers, but not the rice farmers, at the Southwest meeting who seemed to say that they would do whatever was required for weed management, including hand-weeding, to ensure the success of their crops. The high value of these crops in the Southwest region apparently justifies the additional expense and makes it an imperative to use all available tactics. Of course, low commodity prices and resultant poor production economics affect the decisions of every stakeholder (not just the farmers); lenders, farm managers, and landowners also are affected. Thus, this discussion theme differs from the others that relate more to farmers alone. Seven primary areas of economic concern were voiced in the sessions: (1) budget constraints (e.g., lack of affordable financing) for inputs in an environment of low commodity prices; (2) lack of farmer understanding of the long-term economic effects of HR and HRM; (3) land ownership (i.e., whether land was rented or owned by the farmer); (4) availability of resources (e.g., labor, equipment, herbicides) to promptly address HRM issues; (5) incentives to practice HRM; (6) the economics of more diverse weed management practices; and (7) how economics may guide the direction of weed management research.

Several farmers commented that they are struggling to control weeds economically (or within a prescribed budget), but others commented that farmers and lenders are always looking to cut pest management costs, even in good market environments, to capture the highest return on investment. This is, of course, true for all crop production costs. The question we have is whether this desire to optimize production costs, whether in a low price market environment or not, is more of a priority to farmers than worrying about managing HR? In the short term, one's margin is reduced if one spends more money on higher cost programs to control weeds in a more diverse weed management program, if there are no incentives or cost sharing to offset the higher cost.

The participants focused on the current agricultural economy as a reason they are reluctant to spend more to manage $\mathrm{HR}$, but the reality is that economics (i.e., higher monetary or other types of cost) have long been a reason that farmers delay adoption of HRM. Hurley and Frisvold (2016) recently summarized the literature on this subject and, as a summary, stated that because HRM costs are immediate and the benefits of HRM take longer to realize, "farmers are continuously tempted to delay adoption." They also quoted David Miller, Director of Research and Commodity Services, Iowa Farm Bureau Federation, as saying at a National Academies of Science-hosted summit on HR, that "What are the impediments to using best management practices? I believe the primary impediment is the near-term costs associated with implementation of best management practices to forestall a problem that may or may not develop at some unspecified time in the future" (p. 19, NRC 2012). Therefore, although the current agricultural economy may have made this reluctance worse, it already existed years ago.

This is not to say that farmers will not adopt new, more expensive technologies or management strategies if they are forced to or if they see economic and other advantages in doing so. As mentioned above, cotton farmers in Georgia adopted more expensive herbicide, tillage, and hand-weeding practices when they had no choice so as to control HR Palmer amaranth (Sosnoskie and Culpepper 2014). More recently, in 2017 many farmers switched to a weed management system utilizing dicamba-resistant cotton and soybean to increase control of glyphosate-resistant weeds.

The problem remains how to overcome the economic barrier and how to convince farmers to take a longer view of the economic advantages of HRM. In a larger sense, if efficacious herbicides are a common good, allowing for efficient production of affordable food, then whose responsibility is it to bear the cost of preserving their utility? Are the farmers alone in this responsibility, or do they need incentive help from others to fulfill this responsibility? It was interesting that a need for incentives was not a high priority in any of the listening sessions (Table 2). Others have discussed incentives for HRM (Barrett et al. 2016; 
Hurley and Frisvold 2016) and the difficulties with this approach. Hurley and Frisvold (2016) maintained that incentives to foster use of HRM might be feasible in the short term for a crisis, but their costs were not sustainable in the long term. In addition, incentives to overcome short-term cost barriers that are used over the long term become subsidies, not incentives (Barrett et al. 2016). Frisvold et al. (2017) examined incentives to change farmer behavior to switch from reactive to proactive HRM strategies and identified three cases: (1) Incentives are too small to make a proactive strategy more profitable (resulting in farmers not switching); (2) the proactive strategy is already more profitable (resulting in farmers adopting the strategy without incentives); (3) the incentive tips the balance so that the proactive strategy switches from being less profitable to more profitable than the reactive strategy (resulting in farmers being encouraged to switch). Key policy questions are, how many farmers and strategies fall into each of the three categories, and what economic conditions increase the percentage of farmers in the third, positive category where rebates change behavior?

Another concern that was heard a few times was how economics may guide research directions, new-product development, and new HRM approaches. The increased cost of discovery and development of new herbicides and other weed management strategies may be passed onto the users (farmers). This could make any new options for HRM either costly or nonexistent. This economic impediment has disproportionately affected minor crops with small market potential to recapture private and public investment costs (NRC 2010). The competitive (or not) nature of the agriculture supply industry will influence how much of this anticipated cost will be passed to the users or absorbed by the supplier. In reality, though, once new technology is developed, pricing is driven by market value and not the cost basis of the new technology.

Key Theme: We are Aware of Herbicide Resistance but Are Managing It, and We Are Not in a Panic

No one who attended any of the listening sessions expressed a sense of panic that HR weeds were out of control and were unmanageable. However, the Southeast session expressed heightened concern about Palmer amaranth in cotton, although now that those farmers felt they have effective management programs for this weed, the panic seems to have subsided even as farmers acknowledge the greater complexity and cost of the current approaches to control Palmer amaranth. At the same time, statements like those mentioned earlier ("If Liberty ${ }^{\mathrm{TM}}$ fails" and "If we lose Valor ${ }^{\mathrm{TM}}$ and Reflex ${ }^{\mathrm{TM}}$ we could be in trouble") show some recognition that this situation is tenuous and also illustrates the primary reliance on herbicides over other diverse management options for weed control. One conclusion that may come from these listening sessions is that, absent a feeling of panic and given economic pressures to cut costs and think more short-term, farmers and others in the agricultural community may be less receptive to educational messages on $\mathrm{HR}$ or be less willing to change current behavior. However, we need to recognize that there will be a range of responses depending upon the distribution of growers' socioeconomic and biophysical circumstances. As pointed out above, participants did not represent a complete sample of all farmers and their production support networks. Thus, we could have missed individuals who are most concerned about managing resistant weeds. In addition, if most of the participants believe that a new herbicide is coming that will solve their problems, then they would be less likely to be concerned.
Nonetheless, we learned valuable information about the mindsets and perceived challenges and barriers to implementing HRM practices of the listening-session participants. This intelligence will help inform HRM programs going forward.

\section{What Actions Are Needed for HRM?}

After listening to farmers and others involved in weed management decisions across the country and considering what has occurred in the past few years regarding HRM, we consider the following actions to be the next steps for efforts to improve HRM. There are many groups with a role to play. The participants at the listening sessions recommended better communication and coordination among all the groups (a summary of participant input on evaluations is in supplementary materials). As a starting point, we try to segment those roles in the following manner, building on previous discussions (Coble and Schroeder 2016).

\section{Agricultural, Land, and Natural Resource Managers}

HR weeds affect no one group as much as those who manage agriculture, forestry, aquatic, rights-of-way, and natural areas; thus, no one else has as much to gain by making effective HRM decisions. These managers must first educate themselves about the causes of HR and the types of strategic approaches that will help avoid an increase in HR in the future. Choosing sound, science-based information that is appropriate for their local conditions is critical to the success of HRM. Attention to changes in weed populations before and after herbicide applications is essential. Identifying the first occurrence of potential $\mathrm{HR}$ is imperative, and the only way to do that is to monitor fields for treatment effectiveness and properly address any weeds that escape treatment. Working together to limit importation and spread of HR weed seeds across the landscape, region, and states is a key prevention tool. A long-term view of operations is important to the success of HRM.

One of the most successful means of addressing wicked issues in the past was for affected constituents to band together in a community-based approach. Good examples of such groups already exist, and they were most effective when organized by managers who made their own decisions based on their knowledge of local conditions and cropping systems (Ervin and Jussaume 2014; Ervin and Frisvold 2016). The objective would be for affected communities to develop their own plans for longterm HRM strategies.

\section{The Weed Management Input Supply Network}

The weed management input supply network includes herbicide, seed, and equipment companies, the distribution chain, and the retail outlets that supply those products to farmers and farm managers. That network is often the final and most influential source of weed management information in terms of products used (Johnson et al. 2009; Givens et al. 2011). The network members, therefore, must be challenged to consider how providing current, credible, scientifically sound, and nonbiased information to their clients can be included in and enhance their business plan.

In a very real sense, individual companies in the input supply network have the most to lose from HR-their markets. Chemical and seed companies developed and marketed excellent technology for managing weeds in a variety of situations, and that technology helped to create the most efficacious weed control programs in history. Clearly, many cropping systems have not adequately 
integrated that technology with other weed management tools, thus leading to the HR weed problems farmers have today. Hopefully, marketing groups have learned by now that no tool can be used on every field every year without unintended consequences, such as selection for HR weed populations. Chemical and seed marketing groups, probably more than any other member of the input supply community, can provide leadership in HRM through creative marketing programs that integrate a variety of weed management tools at the local level. Companies must find appropriate and legal means of cooperation to encourage an industry-wide effort in providing education and training, as well as individually to offer incentives to promote proper utilization of their technologies and to reward stewardship. Several chemical companies are presently offering incentives to farmers to include, in addition to their own chemistry, a second-MOA herbicide in weed control programs; however, the second herbicide may not always be effective against the target weed. If HR weeds are not already present and if both herbicides are effective, this approach is a good BMP. However, if HR weeds are already present, adding a second MOA does not provide more than one effective MOA on the HR species, and continued use of such a program only sets the stage for future evolved resistance. Additional herbicide use cannot be the only approach for HRM over the long term.

The distribution and retail network usually has the last opportunity to influence weed management decisions on product use. That unique position requires continual education about technology issues and frequent monitoring of local pest conditions so as to be a valid resource. Retail outlets should maintain a relationship with a variety of chemical and seed suppliers to ensure access to the variety of products and inventory necessary to serve clients' needs related to managing HR. Retail agronomists must be certified crop consultants and be impartial with regard to their agronomic recommendations to farmers.

\section{Public-Sector Weed Scientists}

University and government research and extension groups are critical components for the development and implementation of remedies for HRM. Despite the important work done by these groups, the HR weed problem is still growing. In addition to the ongoing work, research is needed to develop economical applications of cover crops, use of diverse crop rotations, and more diverse crop systems, as well as how to incorporate these practices into all facets of farmers' crop production systems. In addition, collaborative work with agricultural engineers, equipment manufacturers, seed dealers, and agencies is needed to reduce seed movement in equipment, seed, and other materials as well as to develop new mechanical weed control technologies.

Clearly, the message about HRM is not being delivered effectively everywhere, meaning that different delivery approaches must be found. Weed scientists need to continue to reach out to the agricultural production community to understand the issues they are facing when managing HR weeds. The weed science community also needs to determine how to reach the audiences who are not currently engaged through traditional outreach efforts. To do this, weed scientists must work with education specialists, social scientists, and even public relations experts, to better understand the decision-making process and how to more effectively impact it through appropriate educational efforts. This also means finding new approaches to weed management that are outside the constraints of existing crop production systems.
Extension educators may play a pivotal role in helping to establish cooperative community-based efforts because of their influential and trusted roles in agriculture (Stallman and James, 2015).

\section{Agronomic Advisors}

Many independent consultants and retail agronomists operate in a service capacity to provide advice on weed management practices. Many of these consultants operate over large acreages and different systems. Because these groups provide advice directly to farmers, it is imperative that they stay current on the latest technology performance characteristics and are aware of trends in their area related to pest resistance issues. Managers need assistance from consultants to develop long-term, local management plans that work for their individual situations. Managers have also indicated that professional certification and the impartiality of consultants is important. Finally, consultants need to play an important role in the education and training of future generations of consultants. They need to share their practical experience and provide opportunities for on-the-ground training to those beginning a career as a consultant.

\section{Government Agencies}

State Departments of Agriculture. State departments of agriculture are responsible for pesticide regulatory enforcement in their state. They need to be informed partners with university extension and the EPA to make the best decisions about pesticide labeling in their states as well as the need for herbicide resistance education as part of the continuing education requirements for pesticide applicator licensing. In addition, state department of agriculture noxious-weed programs can implement regulations, policies, or programs to identify, monitor, and prevent the introduction or spread of weeds (including HR ones) and to assist in their control.

United States Department of Agriculture (USDA) Agriculture Research Service (ARS). The ARS must invest more in basic and applied research in weed science. In addition to these research programs, the ARS has conducted some very successful area-wide pest management programs in the past based on field-ready research programs (Smith and Sheley 2012,; Prosser et al. 2002; Davis and Frisvold 2017). A number of research programs, both in and outside the ARS, are ready for area-wide implementation. Demonstration of the effectiveness of pest management programs in unique areas could be an important step in improved HRM on a wider scale. A current project, "An Integrated Pest Management Approach to Addressing the Multiple Herbicide-resistant Weed Epidemic in U.S. Field Crop Production," was initiated in 2015 in 15 states and is evaluating integrated weed management systems that include harvest weed seed control, herbicides, and cover crops. The experience of the ARS is important for leading effective area-wide program organization. This and other topics need to be conducted on an area-wide basis to demonstrate the effectiveness of integrated weed management programs for farmers and their advisers.

USDA Animal and Plant Health Inspection Service (APHIS). The APHIS does an excellent job of protecting agricultural systems from plant pests [see the Plant Protection Act (PPA) at https:// www.aphis.usda.gov/brs/pdf/PlantProtAct2000.pdf] already present in the United States, new pests from arriving in the United States 
from foreign locations, and noxious weeds that can directly or indirectly injure or cause damage to agriculture from entering the United States without authorization. However, the agency should continue to invest in programs that might help address HR issues, including programs that avoid species from becoming established or moving across geopolitical borders. HR plant species are genetically different from the susceptible genotypes, even though they may look very much the same and may be called the same species. The APHIS should consider working closely within USDA and with the EPA to first use all nonregulatory tools available to delay or avoid the development of HR weeds and to manage those that have become problematic to farmers and other landowners. Should these measures fail to achieve reasonable goals to this end, regulatory approaches will most certainly be the logical progression to managing this challenge.

USDA National Institute for Food and Agriculture (NIFA). The NIFA funds research and extension efforts in agricultural production at land-grant universities and other institutions. Recently, some research funding has been made available for HR efforts. For example, an interdisciplinary group of weed and social scientists were awarded a project, "Integrating Human Behavioral \& Agronomic Practices to Improve Food Security by Reducing the Risk \& Consequences of Herbicide-Resistant Weeds," under the Agriculture Food Research Initiative. A serious commitment of federal research funding is very important in the quest to understand the evolution and spread of HR, to understand the biology and ecology of these driver species, and, based on this understanding, to develop new ways of managing HR and getting information out to farmers and others in the business of agricultural production. Funding is not a one-time need but should be continued. In addition, the NIFA would benefit from having a trained weed scientist in a national program leader position within the agency.

USDA Economic Research Service (ERS). The economics of HRM, particularly multi-year program economics, is a critical component of farmer decision making. Furthermore, interdisciplinary research is needed that examines how farmers balance their need to address multiple management challenges (e.g., weeds, insects, soil fertility) on a limited budget. The ERS is in a position to lead efforts in collaboration with weed scientists to develop this important information. Some good economic information on the profitability of HRM programs, over the long term, is already available within the ERS. Publication of that information in a clear, reader-friendly format and subsequent widespread utilization are critical to the success of HRM at the farm level.

USDA Natural Resources Conservation Service (NRCS). The NRCS has programs that serve as incentives to help farmers with HRM programs. Many of these programs are aimed at soil and water conservation through limited tillage. In addition, programs designed to conserve wildlife and pollinator habitat may restrict tillage, mowing, and herbicide use during nesting season or flowering. However, the presence of HR weeds can cause farmers to discontinue those conservation programs, because tillage is needed to manage those populations. Resistance management may help preserve these important conservation efforts. The NRCS must allow enough flexibility in their conservation programs so that farmers can develop effective HRM programs that include diverse management actions yet adhere to the long-term conservation goal.

USDA Risk Management Agency (RMA). HR adds another risk for agricultural production today. As the risk management agency, The RMA can help manage that risk through programs, such as crop insurance, that might be used to provide incentives for farmers. The RMA should hold discussions with other agricultural agencies and with resource management groups to determine the best way to become involved in helping to manage the great and increasing agricultural risk of HR.

USDA Office of Pest Management Policy (OPMP). The OPMP was established with the mandate to integrate the USDA's activities related to pest management. The OPMP should coordinate and communicate across agencies to make sure that all agencies are involved where appropriate in helping to establish HRM. In addition, the OPMP should also serve as a liaison to the WSSA and other professional societies to ensure that the most current information and resources are available to all USDA agencies.

Environmental Protection Agency (EPA). The EPA has a difficult job in balancing environmental protection with making available the necessary tools for agricultural production. The agency has recently made the decision to include additional HR information on product labels (Anonymous 2017d,e). Requiring a program for monitoring, reporting, and mitigating new cases of HR weeds is an interesting new approach to helping with HRM. The EPA is encouraged to carefully craft, develop, and monitor the effectiveness of this new program and modify the program if needed, and expand the program only as success is documented. The agency should also continue communicating with all institutions involved to make sure appropriate regulatory oversight helps sustain the tools necessary for protecting the agricultural enterprise while fulfilling their statutory obligations for environmental protection.

\section{Resource Management Advocacy Organizations}

Farm organizations and crop commodity groups, plus their companion groups in aquatics, forestry, rights-of-way, and rangeland, represent manager concerns in many areas and have a stake in making HRM work. These groups have great influence on a broad audience including legislators and relevant federal and state agencies. These groups should form strategic alliances among themselves to have an even greater impact at the regional and national level in promoting research, outreach, and education related to HRM. A unified voice and message is strongest.

\section{Professional Societies}

Professional societies represent a focal point for organizing community action and have a responsibility to make sure appropriate and accurate information on HRM is available for decision makers. These societies provide a forum to hear and debate a diversity of opinions regarding the formation of HRM strategies. Professional societies also represent the most likely place for the development and implementation of certification programs for various specializations such as HRM. Professional societies are the best organizations to help form and coordinate the collaborations of all salient groups and to make sure that information is consistent, current and conveys the urgency of the problem. 


\section{Media Outlets}

The agricultural press, radio, and TV have done an outstanding job of getting the word out on HR weeds, and it is an impressive story to tell. These communication outlets serve a critical role in the agricultural community by providing information from a variety of sources that help farmers make decisions and become aware of trends in similar agricultural settings. Their call to action is to keep up the good work and continue to pursue scientifically sound and accountable stories (and to know the difference from those that are not) that can help the farm community with the educational process. It is vital to document HR success stories to assist farmers who are looking for ideas for success in their own management efforts.

In closing, we all recognize that the problem and challenge of HR weeds continues to increase in the United States. Weed scientists have made a great deal of progress in understanding the biology of resistance and identifying diversified strategies for managing resistant weed populations. However, the adoption of these practices has been insufficient to slow the increase in resistance. Further, current weed management approaches may exacerbate the problem if farmers continue to rely on individual (single) technologies for weed control. We need to continue to reach out to farmers and their advisers to fully understand their difficulties to make the changes we suggest. We need to understand and address weed management within the context of the entire farming operation. New interdisciplinary initiatives are needed to bring collaborative action to effectively address resistance throughout the agricultural community. We need to find ways to reach those farmers and groups who do not typically participate in traditional extension programing so as to bring them into the discussion, learn their perspectives, and stimulate action that fits their circumstances. We cannot continue to conduct business as usual if we want to preserve our weed management tools and to create an environment where new technologies can be incorporated into the farming operation successfully. One of the main messages we heard at these listening sessions was that the participants want industry, government, universities, and organizations to communicate more effectively and to work together to address their needs. An approach that requires further exploration and development is organization of groups within local or regional contexts for cooperative efforts in HR management. A variety of good examples of such cooperation already exist, such as the boll weevil eradication program, water management districts, and area-wide weed management programs. In all of these successful examples, stakeholders agreed on the need and led efforts that were supported by academia and state/federal agencies. However, we emphasize that to be successful, no one single approach will work everywhere; rather, each region, state, or even area within a state will have to develop a program that fits its particular context. We think that regional organizations have an important role in leading these collaborative efforts. We also recognize that we require a continuous process of work and sharing between all stakeholder groups to address the problem of managing resistant weeds. The problem of resistant weeds will never disappear and, thus, the "solutions" have to be ongoing.

Supplementary materials. To view supplementary material for this article, please visit https://doi.org/10.1017/wet.2018.49

Acknowledgments. Funds to support the Regional Listening Sessions were provided by the U.S. Department of Agriculture-Animal and Plant Health Inspection Service (Agreement No. 16-2000-0077GR), the United Soybean
Board, and the Weed Science Society of America. The findings and conclusions in this Publication have not been formally disseminated by the U. S. Department of Agriculture and should not be construed to represent any agency determination or policy. The contributions of Bruce Knight and Julie Knight, Strategic Conservation Solutions, LLC, to the success of this effort are gratefully acknowledged. No conflicts of interest have been declared.

\section{References}

Anonymous (2017a) US Inflation Calculator. http://www.usinflationcalculator.com/inflation/historical-inflation-rates/. Accessed: June 19, 2017

Anonymous (2017b) Noxious Weeds. https://agriculture.delaware.gov/plantindustries/noxious-weeds/. Accessed: July 24, 2018

Anonymous (2017c) PRIA Fee Category Table-Registration Division-New Active Ingredients. https://www.epa.gov/pria-fees/pria-fee-category-tableregistration-division-new-active-ingredients. Accessed: September 13, 2017

Anonymous (2017d) PRN 2017-1. Guidance for Pesticide Registrants on Pesticide Resistance Management Labeling. https://www.epa.gov/pesticide-registration/ prn-2017-1-guidance-pesticide-registrants-pesticide-resistance-management. Accessed: October 3, 2017

Anonymous (2017e) PRN 2017-2. Guidance for Herbicide-Resistance Management Labeling, Education, Training, and Stewardship. https:// www.epa.gov/pesticide-registration/prn-2017-2-guidance-herbicide-resistancemanagement-labeling-education. Accessed: October 3, 2017

Anonymous (2017f) Forever Green. https://www.forevergreen.umn.edu/ about/vision. Accessed: January 4, 2018

Anonymous (2018) Farms and Land in Farms. 2017 Summary. United States Department of Agriculture. National Agricultural Statistics Service. http://usda. mannlib.cornell.edu/usda/current/FarmLandIn/FarmLandIn-02-16-2018.pdf. Accessed: July 24, 2018

Barrett M, Soteres J, Shaw DR (2016) Carrots and sticks: incentives and regulations for herbicide resistance management and changing behavior. Weed Sci 64:627-640

Beckie HJ, Reboud X (2009) Selecting for weed resistance: herbicide rotation and mixture. Weed Technol 23:363-370

[CAST] Council for Agricultural Science and Technology (2012) Herbicideresistant weeds threaten soil conservation gains: Finding a balance for soil and farm sustainability. Issue Paper 49. Ames, IA: CAST

Chandi A, Milla-Lewis SR, Jordan DL, York AC, Burton JD, Zuleta MC, Whitaker JR, Culpepper AS (2013) Use of AFLP markers to assess genetic diversity in Palmer amaranth (Amaranthus palmeri) populations from North Carolina and Georgia. Weed Sci 61:136-145

Coble HD, Schroeder J (2016) Call to action on herbicide resistance management. Weed Sci 64:661-666

Davis AS, Hill JD, Chase CA, Johanns AM, Liebman M (2012) Increasing cropping system diversity balances productivity, profitability and environmental health. PLoS ONE 7(10), e47149. https://doi.org/10.1371/ journal.pone.0047149

Davis AS, Frisvold GB (2017) Are herbicides a once in a century method of weed control? Pest Manag Sci 73:2209-2220

Dentzman K, Gunderson R, Jussaume R (2016) Techno-optimism as a barrier to overcoming herbicide resistance: comparing farmer perceptions of the future potential of herbicides. J Rural Studies 48:22-32

Dentzman K, Jussaume R (2017) The ideology of U.S. agriculture: how are integrated management approaches envisioned? Society \& Natural Resources. doi: 10.1080/08941920.2017.1295498

Duke SO (2012) Why have no new herbicide modes of action appeared in recent years? Pest Manag Sci 68:505-512

Duke SO, Powles SB (2008) Glyphosate: a once-in-a-century herbicide. Pest Manag Sci 64:319-325

Ervin DE, Breshears E, Dentzman K, Everman W, Frisvold G, Gunsolus J, Hurley T, Jussaume R, Norsworthy JK, Owen M, Wechsler S (2017) Neighbor and community aspects of herbicide resistance management-insights from a national survey. Accepted presentation. Proc Weed Sci Soc Amer 45:271. http://wssaabstracts.com/public/45/proceedings.html

Ervin DE, Frisvold GB (2016) Community-based approaches to herbicideresistant weed management: lessons from science and practice. Weed Sci 64(sp1):609-626 
Ervin D, Jussaume R (2014) Integrating social science into managing herbicide-resistant weeds and associated environmental impacts. Weed Sci 62:403-414

Ervin D, Wu J, Khanna M, Jones C, Wirkala T (2013) Motivations and barriers to corporate environmental management. Business Strategy and the Environment 22:390-409

Evans JA, Tranel PJ, Hager AG, Schutte B, Wu C, Chatham LA, Davis AS (2016) Managing the evolution of herbicide resistance. Pest Manag Sci 72:74-80

Foresman C, Glasgow L (2008) Grower perceptions and experiences with glyphosate resistant weeds. Pest Manag Sci 64:388-391

Frisvold GB, Bagavathiannan MV, Norsworthy JK (2017) Positive and normative modeling for Palmer amaranth control and herbicide resistance management. Pest Manag Sci 73:1110-1120

Givens WA, Shaw DR, Newman ME, Weller SC, Young BG, Owen MDK, Jordan DL (2011) Benchmark study on glyphosate-resistant cropping systems in the United States. Part 3: Grower awareness, information sources, experiences and management practices regarding glyphosateresistant weeds. Pest Manag Sci 67:758-770

Heap I (2017) The international survey of herbicide resistant weeds. www. weedscience.com. Accessed: November 15, 2017

Hurley TM, Frisvold GB (2016) Economic barriers to herbicide-resistance management. Weed Sci 64(sp1):585-594

Johnson WG, Owen MDK, Kruger GR, Young BG, Shaw DR, Wilson RG, Wilcut JW, Jordan DL, Weller SC (2009) U.S. farmer awareness of glyphosate-resistant weeds and resistance management practices. Weed Technol 23:308-310

Jussaume RA, Dentzman K (2016) Farmers' perspectives on management options for herbicide-resistant weeds. Choices 31:1-7

Livingston M, Fernandez-Conejo J, Unger J, Osteen C, Schimmelpfennig D, Park T, Lambert D (2015) The economics of glyphosate resistance management in corn and soybean production. USDA, Economic Research Service, Economic Research Report No. (ERR-184). Washington, DC: US Department of Agriculture. $52 \mathrm{p}$

Livingston M, Fernandez-Conejo J, Frisvold GB (2016) Economic returns to herbicide resistance management in the short and long run: the role of neighbor effects. Weed Sci 64(sp1):595-608

Llewellyn RS, Lindner RK, Pannell DJ, Powles SB (2002) Resistance and the herbicide resource: perceptions of Western Australian grain growers. Crop Prot 21:1067-1075

Llewellyn RS, Lindner RK, Pannell DJ, Powles SB (2007) Herbicide resistance and the adoption of integrated weed management by Western Australian grain growers. Agric Econ 36:123-130

McDougall P (2016) The Cost of New Agrochemical Product Discovery, Development and Registration in 1995, 2000, 2005-8 and 2010-2014. R\&D expenditure in 2014 and expectations for 2019. A Consultancy Study for CropLife International, CropLife America and the European Crop Protection Association. https://croplife-r9qnrxt3qxgjra4.netdna-ssl.com/wpcontent/uploads/2016/04/Cost-of-CP-report-FINAL.pdf

Neve P, Norsworthy JK, Smith KLZelaya IA (2011) Modelling evolution and management of glyphosate resistance in Amaranthus palmeri. Weed Res 51:99-112
[NRC] National Research Council (2010) The Impact of Genetically Engineered Crops on Farm Sustainability in the United States. Ervin DE, Carrière Y, Cox WJ, Fernandez-Cornejo, Jussaume RA, Marra MC, Owen MDK, Raven PH, Lareesa Wolfenbarger L, Zilberman D, eds. Washington, DC: The National Academies Press. $250 \mathrm{p}$

[NRC] National Research Council (2012) National Summit on Strategies to Manage Herbicide-resistant Weeds. Proceedings of a Workshop. Washington DC: National Academies Press. $66 \mathrm{p}$

Norsworthy JK, Ward SM, Shaw DR, Llewellyn RS, Nichols RL, Webster TM, Bradley KW, Frisvold G, Powles SB, Burgos NR, Witt WW, Barrett M (2012) Reducing the risks of herbicide resistance: best management practices and recommendations. Weed Sci 60(sp1):31-62

Owen MDK (2016) Diverse approaches to herbicide-resistant weed management. Weed Sci 64(sp1):570-584

Owen MDK, Beckie HJ, Leeson JY, Norsworthy JK, Steckel LE (2015) Integrated pest management and weed management in the United States and Canada. Pest Manag Sci 71:357-376

Pates M (2016) Exec: High-tech ag will lead to next Green Revolution. Agweek September 21, 2016. http://www.agweek.com/news/4120366-exec-hightech-ag-will-lead-next-green-revolution. Accessed: November 2, 2017

Prosser CW, Anderson GL, Wendel LE, Richard RD, Redlin BR (2002) TEAM Leafy Spurge: an area wide pest management program. Integrated Pest Manag Rev 7:47-62

Schroeder J, Barrett M, Shaw DR, Asmus AB, Coble H, Ervin D, Jussaume RA, Owen MDK, Burke I, Creech CF, Culpepper AS, Curran WS, Dodds D, Gaines TA, Gunsolus JL, Hanson BD, Jha P, Klodd AE, Kniss AR, Leon RG, McDonald S, Morishita DW, Schutte BJ, Sprague CL, Stahlman PW, Steckel LE, VanGessel MJ (2018) Managing Herbicide Resistance: Listening to the Perspective of Practitioners: Procedures for Conducting Listening Sessions and an Evaluation of the Process. Weed Technol 10.1017/wet.2018.53

Smith B, Sheley RL (2012) Government success in partnerships: the USDA-ARS areawide ecologically based invasive annual grass management program. Rangelands 34:17-24

Sosnoskie LM, Culpepper AS (2014) Glyphosate-resistant Palmer amaranth (Amaranthus palmeri) increases herbicide use, tillage, and hand-weeding in Georgia cotton. Weed Sci 62:393-402

Stallman H, James H Jr (2015) Determinants affecting farmers' willingness to cooperate to control pests. Ecol Econ 117:182-192

Stübler H, Busch M, Strek H (2016) Weed control at the cross roads-which innovations are on the horizon?" Plenary Presentation. Proceedings of the 7th International Weed Science Congress, Prague, Czech Republic, June 19-25, 2016. pp 8-12

Vencill WK, Nichols RL, Webster TM, Soteres JK, Mallory-Smith C, Burgos NR, Johnson WG, McClelland MR (2012) Herbicide resistance: toward an understanding of resistance development and the impact of herbicideresistant crops. Weed Sci 60(sp1):2-30

Walsh M, Newman P, Powles S (2013) Targeting weed seeds in-crop: a new weed control paradigm for global agriculture. Weed Technol 27: $431-436$

Ward SM (2016) Human dimensions of herbicide resistance. Weed Sci 64:551-551 